\title{
Private Strawberry Breeders in California
}

\author{
Thomas M. Sjulin \\ Driscoll Strawberry Associates, Inc., Watsonville, CA 95076-5399
}

Private plant breeders and horticulturists in California have contributed to the genetic improvement of the strawberry (Fragaria $\times$ ananassa Duch.) since the days of the gold rush 150 years ago (Wilhelm and Sagen, 1974). I will discuss three individuals who have made major contributions to that improvement and who left a legacy to be built upon by those who followed.

\section{ALBERT ETTER}

Albert Etter (1872-1950) was born in El Dorado County, Calif., to a German immigrant father who later moved the family to Humboldt County, Calif., along the north coast. Albert's formal education ended at the age of 15 , and he began work on the family farm. When Etter turned 21, he established a homestead in a remote area of Humboldt County. He named his new homestead Ettersburg for the castle in southern Germany where his family originated. It was from this isolated homestead that Etter did his life's work of breeding, propagating and selling new cultivars of strawberries, apples and pears (Darrow, 1963; Wilhelm and Sagen, 1974).

Etter contributed to strawberry improvement in several ways, including 1) early use of both South American and North American clones of the wild beach strawberry ( $F$. chiloensis L.) to improve the adaptability of strawberry cultivars to local conditions; 2) the development of commercially successful cultivars; 3 ) an understanding of the factors influencing flowering and runnering in the strawberry; and 4) a major contribution to the genetics of current cultivars in use throughout North America.

Etter, despite his isolated location, influenced the thinking of strawberry researchers and producers of his day. He did this through frequent correspondence in the Pacific Rural Press, an important agricultural newspaper that at the time was edited by E.J. Wickson, Dean of the University of California (UC) College of Agriculture and a supporter of Etter's work (Fishman, 1987). Etter also influenced strawberry research through observations he recorded in his own nursery catalog (Etter, 1920), and through visits made to his homestead by strawberry researchers, including Roy Clausen, UC geneticist (Clausen, 1915) and George Darrow, strawberry breeder and horticulturist at the U.S. Department of Agriculture (USDA) in Beltsville, Md. (Darrow, 1963).

Etter's use of $F$. chiloensis in his breeding work is well documented (Clausen, 1915; Darrow, 1963, 1966; Etter, 1920; Wilhelm and Sagen, 1974). He recognized that $F$. chiloensis would improve the vigor, drought resistance and fruit size of the cultivated strawberry. Etter used a cultivated clone of $F$. chiloensis from

Peru in the development of his first successful cultivar, 'Rose Ettersburg'. He also crossed a clone of $F$. chiloensis from Cape Mendocino in Humboldt County with 'Rose Ettersburg', and a seedling from the resulting hybrid was introduced as 'Ettersburg 80'. 'Ettersburg 121' was also developed from crosses with $F$. chiloensis, and later cultivars such as 'Fendalcino', 'Trebla', 'Red Cross' and 'Ettersburg 450' were derived in turn from these cultivars and other selections that have $F$. chiloensis clones in their parentage (Etter, 1920).

Several of Etter's cultivars were widely grown. The 'Ettersburg 80' was recognized for its dessert quality, and was grown for canning and jam manufacture in North America, Europe, Australia, and New Zealand. In England, it was renamed 'Huxley' and grown commercially until the 1950 s. Others, such as the 'Fendalcino' were popular home garden cultivars in California (Wilhelm and Sagen, 1974). In Oregon, 'Ettersburg 121 'was second in importance only to 'Marshall', accounting for $29 \%$ of the harvested area in a survey completed in 1925 and 1926 (Schuster and Burrier, 1929). Small percentages of 'Ettersburg 80' and 'Trebla' were also reported in this survey. Oregon at that time was a leading producer of strawberries in the U.S., with more area harvested than California. 'Ettersburg 121' was rated the best cultivar for canning in Oregon (Schuster, 1923), and was grown in that state until the late 1940s, when it was replaced by cultivars better suited to freezing (Waldo and Hartman, 1947).

Etter's correspondence in the Pacific Rural Press also influenced strawberry industry leaders. Joseph E. Reiter, along with R.F. Driscoll, pioneered the development of 'Banner' as a major commercial cultivar along the central coast of California in the early 1900s. Reiter was puzzled by the diminished production of stolons

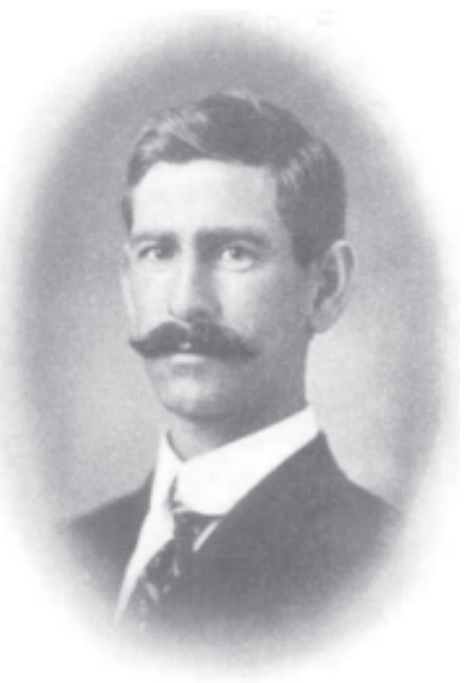

Fig. 1. Albert F. Etter. in this cultivar over several seasons following transplanting to fruiting fields near Watsonville, Calif., from nurseries in the Trinity Mountains of northern California. Reiter commented on this phenomenon in a letter to the Pacific Rural Press. Etter observed, in reply to Reiter's query, that the winters in Watsonville were too mild to stimulate vegetative reproduction. His observation supported the movement of the California strawberry nursery to northern California sites with adequate winter chilling to promote stolon production (Wilhelm and Sagen, 1974).

Etter's greatest legacy to the modern strawberry industry is the genetic contribution of his cultivars to today's cultivars. His cultivars are found in the background of all geographic groups of North American cultivars described by Sjulin and Dale (1987) except the Minnesota group. 'Fendalcino' (developed from 'Ettersburg 121') was a source of virus tolerance in the UC breeding program (Wilhelm and Sagen, 1974) and contributes strongly to the genetics of both public and private California cultivars. 'Ettersburg 450' is believed to be one parent of 'Fairfax', and thus contributes through the widespread use of 'Fairfax' and derivatives in many North American public breeding programs in the first half of the 20th Century (Darrow, 1966). Both 'Ettersburg 121' and 'Ettersburg 450' contribute heavily to Pacific Northwest cultivars. At least three additional founding clones from Etter's work contribute to modern North American cultivars (Sjulin and Dale, 1987).

Etter discontinued his strawberry breeding after 1926, and concentrated on apple and pear breeding. Darrow suspects that diseases introduced on germplasm sent to Etter may have made it difficult for him to continue his work (Darrow, 1966). Whatever the reason, much of Etter's own collection of materialwas lost soon after this time. Some of Etter's cultivars have been re-collected from foreign sources (Fishman, 1987), and at least five of Etter's cultivars ('Ettersburg 121', 'Califour', 'Latecross', 'Red Cross' and 'Trebla') are listed in the Fragaria catalog of the National Clonal Germplasm Repository in Corvallis, Ore. (National Clonal Germplasm Repository, 2003).

\section{EARL V. GOLDSMITH}

Earl Goldsmith (1892-1954) was born at Loma Prieta in Santa Cruz County, Calif. Like Albert Etter, his formal education finished early, as he attended Soquel Grammar School but may not have attended high school. Goldsmith's first horticultural experience was in the fruit orchards of San Jose, and then as foreman at the UC Deciduous Fruit Field Station in San Jose. In 1929, he was promoted to station superintendent, and began his work on strawberries (H.E. Thomas, undated). 


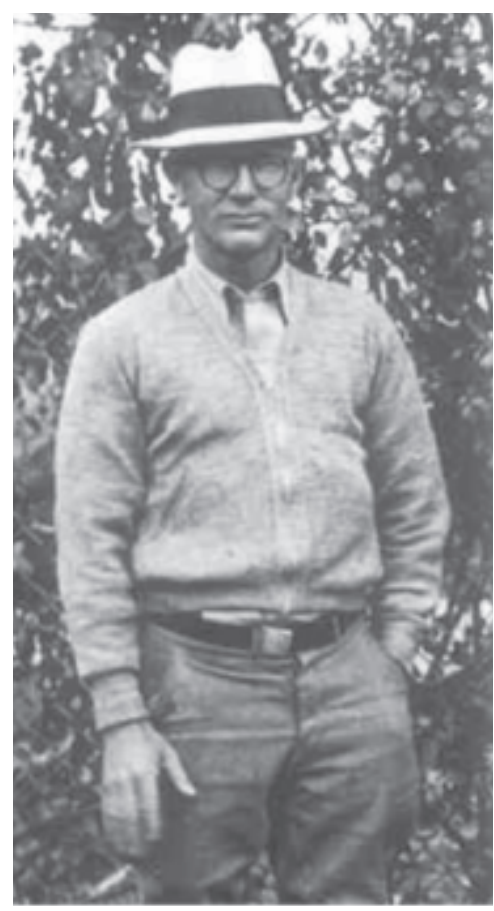

Fig. 2. Earl V. Goldsmith.

Goldsmith began making strawberry crosses in 1929 as a side project at the San Jose station after his daily tasks were completed. University of California plant pathologist $\mathrm{H}$. E. Thomas of Berkeley took charge of the new UC strawberry breeding program about that time, and he joined forces with Goldsmith in what would become a life-long association (Wilhelm, 1954). Thomas provided overall direction to the program, which was focused on developing adapted cultivars that were tolerant to the yellows virus complex that was ravaging the industry. Goldsmith was the "shadow on the ground" that created the specific crosses and made the initial selections. Drawing on a genetically diverse pool of germplasm that included Etter's cultivars, commercial cultivars grown in California such as 'Banner', 'Redheart' and 'Nich Ohmer', and numbered selections from both the USDA in Beltsville and the New York Agricultural Experiment Station in Geneva, these two scientists crossed, selected and intercrossed among these selections for three generations to produce the first five cultivars to be released by this program in 1945 (Thomas and Goldsmith, 1945). These five cultivars and related selections developed by Goldsmith and Thomas constitute most of the germplasm pool from which today's public and private cultivars in California are derived.

Goldsmith and Thomas both left their university positions in the mid-1940s to join the newly created Strawberry Institute of California established by Ned Driscoll and other founders of Driscoll Strawberry Associates (DSA) at Morgan Hill, Calif. Thomas became the director of the institute while Goldsmith was the strawberry breeder. Using cultivars and selections he developed at the UC, Goldsmith continued his method of recurrent selection breeding that he previously described as pyramiding desirable characters (Thomas and Goldsmith, 1945). At DSA, Goldsmith also developed a distinct strawberry ideotype that combined fruit quality with plant characters that improved harvest efficiency. The most representative example of this ideotype turned out to be one of his last accomplishments, the Z5A selection, which was later patented and named the 'Goldsmith' in his honor (Goldsmith and Thomas, 1958). This cultivar was distinctive in its open plant habit and long fruiting cycle combined with large, attractive fruit with good shelf life. This cultivar contributed more than any other developed by the Strawberry Institute to the early success of the DSA organization as a major shipper of fresh strawberries. Unfortunately, Goldsmith did not live to see his cultivar achieve its pinnacle of success, as he died suddenly in 1954, the very year that the first plants of 'Goldsmith' were propagated for commercial release.

Less well known are Goldsmith's contributions to red raspberry (Rubus idaeus L.) breeding. Goldsmith began making raspberry crosses in association with Joseph M. Reiter, son of Joseph E. (see above), in 1937 in the Santa Clara Valley. This work continued off and on until Goldsmith passed away in 1954. Sweetbriar Development Company, a private Rubus research and development company owned by Reiter's descendents and today part of DSA, held a number of Goldsmith's raspberry selections in small trial plots for many years. Stephen Wilhelm began to evaluate some of these selections in the 1970's following his retirement as a plant pathologist from UC Berkeley, and two of these selections were patented and used commercially. One of these, 'Sweetbriar' (Reiter, 1979), was for many years an important fresh market cultivar in California. The raspberry germplasm that Goldsmith left to Wilhelm has contributed much to the present success of the DSA Rubus breeding effort.

\section{HAROLD A. JOHNSON, JR.}

Harold A. (Hal) Johnson, Jr., was born in 1923 in Riverside, Calif., and spent his early years in Santa Barbara, Calif. After graduation from the University of California at Davis, Johnson began work in the Santa Maria, California area in the fertilizer industry. Johnson became acquainted with the Sheehy family of Santa Maria who were farming strawberries for Driscoll Strawberry Associates (DSA). When Earl V. Goldsmith suddenly passed away, the Strawberry Institute of California (now part of DSA) hired Johnson as their strawberry breeder. After H.E. Thomas retired from DSA, Johnson also assumed the duties of vice president of the strawberry research department.

Johnson was a prolific plant breeder during his tenure at DSA. Beginning with the E2 cultivar patented in 1966 (U.S. Plant Patent 2,611) and ending with the 'E26' patented in 1991 (U.S. Plant Patent 7,522), Johnson and his colleagues at DSA discovered, patented and commercialized 38 strawberry cultivars. Many of these cultivars played an important role in DSA's successful growth and current position as the leading strawberry shipper in the world. The steady succession of improved cultivars allowed DSA to expand its area of production beyond its original base in the Salinas-Watsonville district, while simultaneously featuring unique, high-quality fruit in its flagship Driscoll label.

One of the most noteworthy varieties developed by Johnson and his colleagues was 'Heidi' (Johnson and Thomas, 1972), which was the first cultivar for the central coast of California that combined a strong summer production cycle with attractive, flavorful fruit. 'Heidi', more than any other cultivar developed at DSA, helped distinguish DSA as the premier shipper of California strawberries. Finding a replacement for 'Heidi' proved difficult, but several new cultivars released in the late 1980s, most notably 'Commander' (Johnson et al., 1989), were significant improvements. Johnson also established high standards of quality for early spring cultivars in southern California with the introduction of 'Thomas' (Johnson, 1983) and 'Joe Reiter' (Johnson, 1984). His final release, 'E26' (Johnson et al., 1991), was instrumental in the development of a summerplanted everbearing production system for late autumn-early winter production in southern California. This production system filled the remaining window in the California production cycle, allowing DSA to ship strawberries from that state every week of the year.

Johnson, building on the organization established by H.E. Thomas, established DSA's research department as a world-renown organization. He continued his own personal development by completing his MS in plant pathology at UC-Berkeley in 1965, under the direction of Stephen Wilhelm. He brought entomologists, plant pathologists and additional plant breeders into the department, and maintained strong professional ties with the academic community. Johnson believes that a balance must be struck between improvement of horticultural traits, including consumer traits, and improvement of pest and disease resistance to ensure the long-term prosperity of

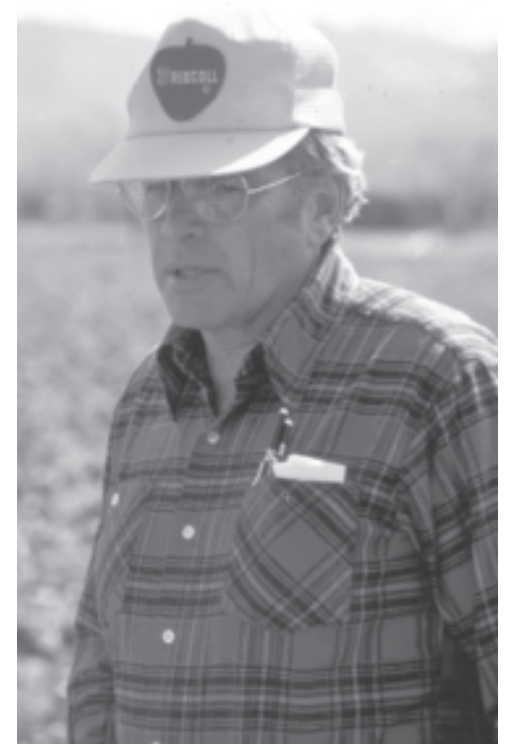

Fig. 3. Harold A. Johnson. 
the strawberry industry (Johnson, 1990). Johnson also has one of the strongest work ethics of anyone I've ever met. He never feels that a job is beneath him, and quite often during his tenure at DSA he could be found in the middle of a muddy field helping dig nursery stock or mapping a new seedling planting.

My colleagues and I at DSA have benefited tremendously from the germplasm and legacy he established during his career. His insistence that high standards of flavor and eye appeal be maintained in all cultivars made finding an improved cultivar more difficult, but that has helped DSA achieve a high level of brand recognition in the U.S. produce industry. When he retired from full-time status in 1988, he left us with a strong pool of advanced germplasm from which we have been able to develop even better cultivars. New cultivars developed since 1988 for all areas including California, Florida, Mexico, and Europe have been derived in large part from this pool of germplasm.

Johnson typically has not been able to simply retire since 1988 . He assisted me in the early years of my tenure as head plant breeder at DSA, not only providing insight based on his years of experience but also taking off my shoulders some of the less-enjoyable tasks such as preparing patent documents. This allowed me to focus on the plant breeding effort and to expand the program into new geographic areas. Johnson continues to be involved in the strawberry industry today, assisting the Plant Sciences, Inc., breeding program established by his former DSA colleague, Richard Nelson.

\section{Literature Cited}

Clausen, R.E. 1915. Ettersburg strawberries. J. Hered. 6:324-331.

Darrow, G.M. 1963. Albert F. Etter-Strawberry breeder. Fruit Var. Hort. Dig. 17:69-72.

Darrow, G. M. 1966. The strawberry: history, breeding and physiology. Holt, Rinehart and Winston, New York.

Etter,A.E. 1920. Ettersburg strawberries describing varieties and breeding methods as practiced at Etter Experimental Place, Ettersburg, Humboldt County. Eureka Printing Co., Eureka, Calif.

Fishman, R. 1987. Albert Etter: Fruit breeder. Fruit Var. J. 41:40-46.

Goldsmith, E.V., and H.E. Thomas. 1958. Variety of strawberry. U.S. Plant Patent 1,735.

Johnson, Jr., H.A.. 1983. Strawberry plant. U.S. Plant Patent 5,071.

Johnson, Jr., H.A.. 1984. Strawberry plant-'Joe Reiter'. U.S. Plant Patent 5,300.

Johnson, Jr., H.A.. 1990. The contributions of private strawberry breeders. HortScience 25:897-902.

Johnson, Jr., H.A., T.M. Sjulin, A.Q. Amorao, and J.I. Espejo, Jr. 1991. Strawberry plant named 'E26'. U.S. Plant Patent 7,522.
Johnson, Jr., H.A., D.W. Small, A.Q. Amorao, and J.I. Espejo, Jr. 1989. Strawberry plant 'Commander'. U.S. Plant Patent 7,024.

Johnson, Jr., H.A. and H.E. Thomas. 1972. Strawberry plant. U.S. Plant Patent 3,123.

National Clonal Germplasm Repository. 2003. NCGR-Corvallis Fragaria Catalog. http:// www.ars-grin.gov/cor/catalogs/fracult.html.

Reiter, J.M. 1979. Raspberry plant. U.S. Plant Patent 4,486

Schuster, C.E. 1923. Strawberries. Ore. Agr. College Expt. Sta. Circ. 32

Schuster, C.E. and A.S. Burrier. 1929. Cost and practices in strawberry production in the Willamette valley. Ore. State Agr. College Agr. Exp. Sta. Bul. 245.

Sjulin, T.M. and A. Dale. 1987. Genetic diversity of North American strawberry cultivars. J. Amer. Soc. Hort. Sci. 112:375-385.

Thomas, H.E. No date. Unpublished notes on the life of Earl V. Goldsmith.

Thomas, H.E. and E.V. Goldsmith. 1945. The Shasta, Sierra, Lassen, Tahoe, and Donner strawberries. Univ. Calif. Agr. Expt. Sta. Bul. 690.

Waldo, G.F., and H. Hartman. 1947. Strawberry productin in Oregon. Ore. State College Agr. Expt. Sta. Bul. 442.

Wilhelm, S. and J.E. Sagen. 1974. A history of the strawberry from ancient gardens to modern markets. Univ. Calif. Div. Agr. Sci., Berkeley, Calif.

Wilhelm, S. 1954. California's foremost strawberry breeder. Amer. Fruit Grow. 74:12A, 12D. 